\title{
THE EFFECT OF SKIN CONTACT ON THE AROMATIC COMPOSITION OF THE WHITE WINE OF VITIS VINIFERA L. CV. MUSCAT OF ALEXANDRIA GROWN IN SOUTHERN ANATOLIA
}

\author{
T. CABAROGLU* and A. CANBAS \\ Çukurova University, Faculty of Agriculture, Department of Food Engineering, 01330 - Adana. Turkey \\ (Received: 13 December 2000; accepted: 27 September 2001)

\begin{abstract}
Free and bound aroma (precursors) compounds of the Muscat of Alexandria wines and the effect of skin contact $\left(7 \mathrm{~h}\right.$, at $\left.15^{\circ} \mathrm{C}\right)$ on aroma composition have been investigated. The aroma compounds, extracted with the pentan-dichloromethane (2:1) method and Amberlite XAD-2 resin, were analysed by gas chromatography (GC) and gas chromatography-mass spectrometry (GC-MS). A total of 41 free volatile compounds (12 esters, 8 acids, 7 terpenes, 5 alcohols, 4 phenols, 3 C- 6 compounds, 2 carbonyl compounds) and 28 bound compounds (10 terpenes, 2 alcohols, 2 C- 6 compounds, 5 fatty acids, 6 phenols, 2 C-13 norisoprenoids, 1 carbonyl compound) were identified in Muscat of Alexandria wines. Skin contact treatment increased the total free and bound aroma compound levels, and improved the wine quality by affecting the intensity as well as the quality of aroma.
\end{abstract}

Keywords: skin contact, aroma, white wine, precursors, Muscat of Alexandria

Hitherto several techniques have been used to obtain maximum intensity of the characteristic varietal aromas in muscat and related aromatic grape varieties. One of them is skin contact. Certain aroma compounds are predominant in grape skins (GuNATA et al., 1985a; WILSON et al., 1986; GoMEZ et al., 1994) and they are present partly as free, volatile forms and partly as glycosidically-bound, non-volatile precursors (GUNATA et al., 1986). Consequently, skin contact between juice and skins prior to pressing generally results in higher concentrations of aroma compounds in the juices and corresponding wines (BAUMES et al., 1989a, b; MOYANO et al., 1994; CABAROGLU et al., 1997). The increase could be caused by the transformation of free aroma compounds (DI STEFANO, 1981) and the liberation of aroma compounds from their nonvolatile bound glycosidic form (WILLIAMS et al., 1980; DUGELAY et al., 1993). However, contact of the must with grape skins may also result in increasing the concentration of phenolic compounds which may be detrimental to white wine quality (ARNOLD \& NOBLE, 1979; SINGLETON et al., 1980; TEST et al., 1986). In addition, skincontact technique frequently displays higher colour intensity and sensitivity to oxidation of white wines (CHEYNIER et al., 1989; MACHEIX et al., 1991). The success of this

\footnotetext{
* To whom correspondence should be addressed. Tel: 90322 3386997; Fax: 90322 3386173;

E-mail: tcabar@mail.cu.edu.tr
} 
technique seems to depend not only on skin contact conditions but also on the grape cultivar (ARNOLD \& NOBLE, 1979; CABAROGLU et al., 1997).

Muscat of Alexandria, which is known as Muscat of Iskenderiye in Turkey, is produced widely in Ege and Akdeniz region in Turkey (Southern Anatolia) (ANON, 1990a). Till now, advanced studies have been carried out on the characteristic aroma of muscat grapes and wines (HARDY, 1970; BAYONOVE \& CORDONNIER, 1971; RIBEREAUGAYON et al., 1975; GUNATA et al., 1985a). White cultivar wines, produced in warm wine producing countries, often lack sufficient and characteristic aromas (MARAIS \& RAPP, 1988). The aromatic composition of Muscat of Alexandria wines produced in Turkey has not been reported yet. This study was conducted to investigate the effect of skin contact on wine quality as well as the free and bound aroma (precursors) composition of Muscat of Alexandria wines.

\section{Materials and methods}

\section{1. Wine samples}

Healthy grapes $(150 \mathrm{~kg})$ from Vitis vinifera $\mathrm{L}$. cv. Muscat of Alexandria grown at the University's experimental vineyard in Çukurova, Akdeniz region of Turkey, were manually harvested and transported to the experimental winery at the Department of Food Engineering, Faculty of Agriculture, University of Çukurova. Grapes were divided into two parts. One was treated in the standard way with minimal skin contact: grapes were pressed in a horizontal press and $50 \mathrm{mg} \mathrm{l}^{-1}$ of sulphur dioxide was added. The juice was then settled at $15{ }^{\circ} \mathrm{C}$ for $24 \mathrm{~h}$ and racked. For the skin-contact experiment, the grapes were destemmed and crushed. The pomace was mixed with $50 \mathrm{mg} \mathrm{kg}^{-1}$ of sulphur dioxide, kept at $15{ }^{\circ} \mathrm{C}$ for $7 \mathrm{~h}$ and then pressed in a horizontal press. The juice was settled and racked as mentioned above. Both batches spontaneously fermented at $18{ }^{\circ} \mathrm{C}$. During fermentation, the decrease in juice density was checked twice daily. When most of the lees settled the wines were racked, $50 \mathrm{mg} \mathrm{l}^{-1}$ of sulphur dioxide was added, and the wine was stored at $15{ }^{\circ} \mathrm{C}$ in tanks.

\section{2. Standard chemical analysis}

Wines were analysed for ethanol, extract, $\mathrm{pH}$, total acidity, volatile acidity, ash, ash alkalinity and potassium by the methods in standard use for wines as recommended by OIV (ANON, 1990b). Total phenolics was measured as the absorbance at $280 \mathrm{~nm}$ on 1/100 dilution of wine by spectrophotometric method (RIBEREAU-GAYON et al., 1976). Colour was measured as the absorbance at $420 \mathrm{~nm}$ as recommended by SINGLETON \& KRAMLING (1976).

\section{3. Free and bound aroma compounds analysis}

Before extraction, $30 \mu \mathrm{g}$ of 4-nonanol (Fluca 98\%) was added to the wine samples $(100 \mathrm{ml})$ as internal standard for free aroma compounds because of its high recovery 
(VoIRIN et al., 1992a). Amberlit XAD-2 resin (20-50 mesh, Merck) was used to isolate free and glycosidically bound aroma compounds (GUNATA et al., 1985b). This polymeric adsorbent was chosen as it had the advantage that free and glycosidically bound aroma compounds can be isolated and separated in one sample preparation step. The samples were eluted through an Amberlite XAD-2 column $(120 \mathrm{~mm} \times 7 \mathrm{~mm}$ i.d. $)$ with $1.5 \mathrm{ml} \mathrm{min}^{-1}$ flow rate. The free and bound compounds were eluted successively with $50 \mathrm{ml}$ each of pentane-dichloromethane (2:1) and ethyl acetate-methanol (9:1) (CABAROGlu et al., 1997). Pentane-dichloromethane eluate was dried over anhydrous sodium sulphate, and then concentrated by fractional distillation through a Vigreux column prior to GC and GC-MS analysis. The ethyl acetate/methanol eluate was concentrated to dryness in vacuum and dissolved in $0.2 \mathrm{ml}$ of $0.2 \mathrm{M}$ citrate-phosphate buffer (pH 5.0). For enzymatic release of aglycones, $1.2 \mathrm{mg}$ of Pektolase 3PA (Grinsted, France) was added to this extract and the mixture was incubated at $40{ }^{\circ} \mathrm{C}$ for $12 \mathrm{~h}$. Released aglycones were extracted with pentane-dichloromethane and the organic layer, after addition of $30 \mu \mathrm{g}$ of 4-nonanol as standard, was concentrated and then analyzed by GC and GC-MS. GC analysis of free and released volatile compounds was performed using a Shimadzu GC-14B Chromatograph equipped with a fused capillary column coated with DB-Wax $(30 \mathrm{~m} \times 0.32 \mathrm{~mm}$ i.d., $0.5 \mu \mathrm{m}$ film thickness, JW, Folsom, CA, USA). On column injector was used and programmed from 20 to $250{ }^{\circ} \mathrm{C}$ at $180{ }^{\circ} \mathrm{C} \mathrm{min}^{-1}$. Oven temperature was at $60{ }^{\circ} \mathrm{C}$ for $3 \mathrm{~min}$, from 60 to $220^{\circ} \mathrm{C}$ at $2{ }^{\circ} \mathrm{C} \mathrm{min}-1$, from 220 to $245^{\circ} \mathrm{C}$ at $3{ }^{\circ} \mathrm{C} \mathrm{min}^{-1}$, then held for $20 \mathrm{~min}$. The FID temperature was $250^{\circ} \mathrm{C}$. The carrier gas was helium with a flow rate of $1.1 \mathrm{ml} \mathrm{min}^{-1}$.

Identification was performed using a "Hewlett Packard (HP)-5890 Series II" gas chromatograph coupled to a "HP 5989A" series mass spectrometer with a quadrupole mass filter. The GC conditions and the capillary column were the same as described above. Mass spectra were recorded in the electron-impact (EI) mode. Source temperature was $250{ }^{\circ} \mathrm{C}$. Mass spectra were scanned at $70 \mathrm{eV}$ in the range $\mathrm{m} / \mathrm{e}$ 29-350 at 1-s intervals. Identifications were carried out by comparing retention times and EI mass spectra with published data or with authentic compounds (VoIRIN et al., 1992b).

Concentrations of aroma compounds were calculated using 4-nonanol as internal standard. The statistical significance of the effect of the skin contact on free and bound aroma compound concentrations obtained in duplicate analyses (three injections for each replication) was determined by analysis of variance (Anova).

\section{Results and discussion}

\section{1. General wine composition}

The wine composition obtained from skin contact differed from the control wine, as is shown in Table 1. The wine made with skin contact had higher values for $\mathrm{pH}$, extract, ash, ash alkalinity, potassium-, phenolic content, and lower values for ethanol, total acidity and volatile acidity. This increase was the consequence of skin compounds being extracted into the juice as reported previously (SINGLETON et al., 1980; DUBOURDIEU et 
al., 1986; RAMEY et al., 1986). As expected, absorbance at $280 \mathrm{~nm}$ and absorbance at $420 \mathrm{~nm}$ increased with skin contact, probably because of the same causes. Total phenolics and colour of wines are known to be affected by skin contact treatment (OUGH, 1969; SINGLETON et al., 1980; TEST et al., 1986). It has been reported that skin contact caused an increase in flavonoid content of the juice, and this increase raised the absorbance at $420 \mathrm{~nm}$ and browning capacity (SINGLETON \& KRAMLING, 1976; SINGLETON, 1974).

Table 1. Composition of Muscat of Alexandria wines ${ }^{\mathrm{a}}$

\begin{tabular}{lcc}
\hline & Control & Skin-contact \\
\hline Ethanol (\% v/v) & 10.26 & 10.03 \\
Titratable acidity $\left(\mathrm{meq}^{-1}\right)$ & 80 & 75 \\
PH & 3.20 & 3.35 \\
Volatile acidity $\left(\mathrm{meq} \mathrm{l}^{-1}\right)$ & 6.0 & 4.1 \\
Absorbance at $280 \mathrm{~nm}^{-1}$ & 0.025 & 0.047 \\
Absorbance at $420 \mathrm{~nm}$ & 0.058 & 0.067 \\
Ash $\left(\mathrm{g} \mathrm{l}^{-1}\right)$ & 1.46 & 1.54 \\
$\mathrm{~K}\left(\mathrm{mg} \mathrm{l}^{-1}\right)$ & 901 & 978
\end{tabular}

${ }^{\mathrm{a}}$ The results are given as mean values of triplicates (maximum SD: $\pm 5 \%$ )

\section{2. Free fraction of aroma compounds of the wines}

A total of 41 free volatile compounds were identified in Muscat of Alexandria wines by GC-MS, including 12 esters, 8 acids, 7 terpenes, 5 alcohols, 4 phenols, 3 C-6 compounds, 2 carbonyl compounds (Table 2). Nevertheless, there were no qualitative differences between control and skin contact wines, and the concentration of volatile aroma compounds was higher in the latter, as had been previously reported (BAUMES et al., 1989a, b; FALQUE \& FERNANDEZ, 1996; CABAROGLU et al., 1997). The control and skin contact wines contained 102.0 and $118.9 \mathrm{mg} \mathrm{l}^{-1}$ of volatiles, respectively, and the amounts of several compounds were significantly different. Skin contact caused significant increases in the total concentration of alcohols, esters and terpenes (Table 2). Alcohols were the most abundant compounds of Muscat of Alexandria wines, followed by acids, esters, C-6 compounds, terpenes, phenols and carbonyl compounds.

Among the alcohols, 3-methyl-1-butanol and 2-phenylethanol were the major alcohols in the wines. Skin contact treatment increased the total level of the alcohol compounds significantly. Except for 3-methyl thio-1-propanol, all compounds were increased significantly by skin contact (Table 2). Similar findings have been reported by BAUMES and co-workers (1989a) and FALQUE \& FERNANDEZ (1996). From the alcohols identified, 2-phenylethanol and benzylalcohol are favourable aroma compounds of wines (NYKANEN \& SUOMALAINEN, 1989; ETIEVANT, 1991). 
Table 2. Effect of skin-contact on free aroma compound levels of Muscat of Alexandria wines ${ }^{\mathrm{a}}$

\begin{tabular}{|c|c|c|c|}
\hline Compound $\left(\mu \mathrm{g}^{-1}\right)$ & Control & Skin-contact & $\mathrm{Sig}^{\mathrm{b}}$ \\
\hline \multicolumn{4}{|l|}{ Alcohols } \\
\hline 2-methyl-1-propanol & $902 \pm 31.11$ & $1628 \pm 73.53$ & ** \\
\hline 3-Methyl-1-butanol & $66922 \pm 898.9$ & $77510 \pm 1029.5$ & ** \\
\hline 3-methylthio-1-propanol & $24 \pm 7.48$ & $50 \pm 10.34$ & $\mathrm{~ns}$ \\
\hline Benzyl alcohol & $47 \pm 2.82$ & $72 \pm 5.65$ & $*$ \\
\hline 2-Phenyl ethanol & $16372 \pm 540.2$ & $20959 \pm 1299.6$ & $*$ \\
\hline Total of alcohols & $84267 \pm 1480.5$ & $100219 \pm 2418.5$ & $* *$ \\
\hline \multicolumn{4}{|l|}{ C-6 alcohols } \\
\hline 1-Hexanol & $820 \pm 25.45$ & $983 \pm 16.97$ & $*$ \\
\hline E-3-Hexen-1-ol & $106 \pm 16.97$ & $189 \pm 21.21$ & * \\
\hline Z-3-Hexen-1-ol & $104 \pm 31.11$ & $86 \pm 8.48$ & ns \\
\hline Total of C-6 alcohols & $1030 \pm 73.53$ & $1258 \pm 46.66$ & $n s$ \\
\hline \multicolumn{4}{|l|}{ Terpenes } \\
\hline Linalol & $60 \pm 5.99$ & $68 \pm 4.24$ & ns \\
\hline$\alpha$-Terpineol & $295 \pm 14.14$ & $400 \pm 24.04$ & $*$ \\
\hline Geraniol & $84 \pm 0.99$ & $98 \pm 3.10$ & $* *$ \\
\hline 3,7-Dimethyl-1,5-octadiene-3,7-diol & $65 \pm 2.41$ & $241 \pm 30.11$ & * \\
\hline Linalol hydrate & $38 \pm 2.82$ & $94 \pm 15.55$ & $*$ \\
\hline 3,7-Dimethyl-1,5-octadiene-3,8-diol & $1113 \pm 7.28$ & $120 \pm 12.40$ & ns \\
\hline Geranic acid & $156 \pm 6.75$ & $167 \pm 2.96$ & ns \\
\hline Total of terpenes & $811 \pm 40.38$ & $1188 \pm 92.40$ & $*$ \\
\hline \multicolumn{4}{|l|}{ Esters } \\
\hline Ethyl butanoate & $303 \pm 24.25$ & $448 \pm 36.56$ & * \\
\hline 3-Methylbutyl acetate & $1124 \pm 84.85$ & $1622 \pm 92.83$ & $*$ \\
\hline Ethyl hexanoate & $288 \pm 26.87$ & $443 \pm 28.28$ & $*$ \\
\hline Ethyl lactate & $820 \pm 56.60$ & $781 \pm 8.48$ & ns \\
\hline Ethyl octanoate & $388 \pm 20.81$ & $381 \pm 24.04$ & ns \\
\hline Ethyl benzoate & $21 \pm 4.24$ & $26 \pm 4.98$ & ns \\
\hline Ethyl succinate & $116 \pm 29.69$ & $151 \pm 18.38$ & ns \\
\hline Ethyl 4-hydroxy-butanoate & $87 \pm 9.79$ & $147 \pm 26.87$ & $*$ \\
\hline 2-Phenylethyl acetate & $189 \pm 29.69$ & $300 \pm 10.79$ & $*$ \\
\hline Diethyl malate & $189 \pm 18.38$ & $443 \pm 25.45$ & $* *$ \\
\hline Ethyl hydroxy-glutarate & $749 \pm 53.74$ & $800 \pm 10.07$ & ns \\
\hline Monoethyl succinate & $862 \pm 40.08$ & $1071 \pm 94.75$ & ns \\
\hline Total of esters & $5136 \pm 398.99$ & $6613 \pm 381.48$ & $*$ \\
\hline \multicolumn{4}{|l|}{ Fatty acids } \\
\hline Isobutanoic acid & $12 \pm 2.82$ & $16 \pm 5.65$ & ns \\
\hline Butanoic acid & $48 \pm 9.89$ & $58 \pm 11.31$ & ns \\
\hline Isovaleric acid & $67 \pm 4.24$ & $46 \pm 8.48$ & ns \\
\hline Hexanoic acid & $3300 \pm 648.52$ & $3928 \pm 138.59$ & ns \\
\hline Octanoic acid & $5230 \pm 377.24$ & $3780 \pm 191.73$ & $*$ \\
\hline Decanoic acid & $970 \pm 155.56$ & $541 \pm 38.18$ & ns \\
\hline Tetradecanoic acid & $178 \pm 32.52$ & $172 \pm 36.46$ & $\mathrm{~ns}$ \\
\hline Hexadecanoic acid & $439 \pm 18.38$ & $482 \pm 84.45$ & ns \\
\hline Total of acids & $10244 \pm 1249.16$ & $9023 \pm 514.85$ & ns \\
\hline
\end{tabular}


Table 2. continued

\begin{tabular}{lcrc}
\hline Compound $\left(\mu \mathrm{g}^{-1}\right)$ & \multicolumn{1}{c}{ Control } & Skin-contact & Sig $^{\mathrm{b}}$ \\
\hline Phenols & & & \\
$\quad$ Vanilline & $23 \pm 0.8$ & $29 \pm 1.41$ & $*$ \\
Syringaldehyde+4-hydroxy benzaldehyde & $125 \pm 14.70$ & $139 \pm 21.21$ & $\mathrm{~ns}$ \\
Acetosyringone & $65 \pm 5.65$ & $69 \pm 4.47$ & $\mathrm{~ns}$ \\
Tyrosol & $250 \pm 17.34$ & $242 \pm 20.68$ & $\mathrm{~ns}$ \\
$\quad$ Total of phenols & $\mathbf{4 6 3} \pm \mathbf{3 8 . 4 9}$ & $\mathbf{4 7 9} \pm \mathbf{4 7 . 7 7}$ & $\mathbf{n s}$ \\
Carbonyl compound & $161 \pm 15.55$ & $179 \pm 17.18$ & $\mathrm{~ns}$ \\
$\quad$ 4-Carbethoxy- $\boldsymbol{\gamma}$-butyrolactone & $\mathbf{1 0 2 0 9 2}$ & $\mathbf{1 1 8 9 5 9}$ & \\
$\quad$ Total of volatiles & &
\end{tabular}

${ }^{a}$ The results are given as mean of two replications (six injections on GC) with standard deviations

${ }^{\mathrm{b}}$ Sig: Significance at which means differ as shown by analysis of variance; * ** denote significances at $\mathrm{P}<0.05$ and $\mathrm{P}<0.01$, respectively; ns: not significant

With regard to C-6 compounds, hexanol was the most abundant compound in the wines. The total concentration of C-6 alcohols was increased by skin contact, as has been reported previously (BAUMES et al., 1989a; CABAROGLU et al., 1997). However, the increase was small and not significant. As it has been known, C-6 compounds have herbaceaus and leafy odour and detract from wine aroma. Their concentrations in Muscat of Alexandria wines were below their taste thresholds (ETIEVANT, 1991).

Among the terpenes identified, $\alpha$-terpineol was the compound with the highest amount in the control and skin contact wine. Terpenes are responsible for the characteristic aroma of muscat cultivars and aroma related wines (MARAIS, 1983). The total concentration of terpenes increased significantly due to the skin contact. This treatment resulted in significant increase in the concentrations of $\alpha$-terpineol, geraniol, 3,7-dimethyl-1,5-octadien-3,7-diol and linalool hydrate. Previous studies showed that terpene compounds were mainly located in the skin and the solid parts of the cells, and skin contact improved the quality of aroma increasing the concentration of terpenes (GUNATA et al., 1985a; MARAIS \& RAPP, 1988; GOMEZ et al., 1994; BAUMES et al., 1989b; MARAIS, 1983).

In the case of esters 3-methylbutyl acetate, monoethyl succinate, ethyl lactate and ethyl hydroxy glutarate were the major esters of Muscat of Alexandria wines. Esters are one of the most important compounds in the aroma of wines due to the fact that they provide delicate odours to wines (ETIEVANT, 1991). Skin contact caused a significant increase in the total concentration of esters as reported previously (BAUMES et al., 1989a; FAlQue \& FERNANDEZ, 1996). From the esters identified, ethyl butanoate, 3methylbutyl acetate, ethyl hexanoate, ethyl 4-hyroxy-butanoate, 2-phenylethyl acetate and diethyl malate levels increased significantly with the skin contact treatment. 
Hexanoic acid and octanoic acid were the most abundant fatty acids in Muscat of Alexandria wines. While certain fatty acid levels (i.e. isobutanoic, butanoic, hexanoic, hexadecanoic) increased with the skin contact treatment, others (i.e. isovaleric, octanoic, decanoic, tetradecanoic) decreased. However, the differences between the concentrations of the acids were significant only for octanoic acid. Thus, it can be said that skin contact treatment does not seem to have a significant effect on the fatty acids levels.

With regard to volatile phenols, the skin contact treatment resulted in increases in total phenol concentration and individually, in vanilline and acetosyringone concentrations. However, only vanilline level was significantly different. Syringaldehyde concentration was not determined, as it coeluted in GC analysis with 4-hydroxy benzaldehyde.

Only 4-carbethoxy- $\gamma$-butyrolactone and 4-hydroxy benzaldehyde were detected in Muscat of Alexandria wines as carbonyl compounds. 4-Carbethoxy- $\gamma$-butyrolactone was at higher concentration in the skin contact wine than the control, however, the difference between the concentrations was not significant.

\section{3. Bound fraction of aroma compounds of the wines}

A total of 28 bound compounds were identified in Muscat of Alexandria wines by GCMS, including 10 terpenes, 2 alcohols, 2 C- 6 compounds, 5 fatty acids, 6 phenols, 2 C13 norisoprenoids, 1 carbonyl compound (Table 3). The total concentrations of bound aroma released by enzyme hydrolysis in control and skin contact treated wines were 1583 and $2348 \mu \mathrm{g} 1^{-1}$, respectively. Skin contact treatment increased considerably the total concentration of bound compounds as previously reported (BAUMES et al., 1989b; CABAROGLU et al., 1997). Terpenes were the most abundant bound compounds in Muscat of Alexandria wines followed by phenols, alcohols and acids.

Skin contact resulted in significant increase in the total concentration of terpenes, alcohols and norisoprenoids. Largest increases were found in terpenes. Among them, $\alpha-$ terpineol, trans-pyran linalool oxide, citronellol, nerol, geraniol, 3,7-dimethyl-1,5octadien-3,7-diol, linalool hydrate and 3,7-dimethyl-1,7-octadien-3,6-diol levels increased significantly with skin contact treatment. Muscat wines made with skin contact were richer in terpenes due to high levels of terpenes in berry skin (GUNATA et al., 1985a; BAUMES et al., 1989b). On the other hand, bound benzylalcohol, 2-phenylethanol, benzoic acid, 4-vinylguaiacol, 4-vinylphenol, 3-hydroxy- $\beta$-damascone and 3-oxo- $\alpha$-ionol levels increased significantly with skin contact treatment. A number of studies have shown that these compounds occur in grapes in glycosidic form (Williams et al., 1989; VoIRIN et al., 1990; SEFTON et al., 1993). The increase in bound aroma concentrations as a result of skin contact were reported previously (CABAROGLU et al., 1997). 
Table 3. Effect of skin-contact on bound aroma compound levels of Muscat of Alexandria wines ${ }^{\mathrm{a}}$

\begin{tabular}{|c|c|c|c|}
\hline Compound $\left(\mu \mathrm{g} \mathrm{l}^{-1}\right)$ & Control & Skin-contact & $\mathrm{Sig}^{\mathrm{b}}$ \\
\hline \multicolumn{4}{|l|}{ Alcohols } \\
\hline Benzyl alcohol & $34 \pm 5.65$ & $64 \pm 8.54$ & $*$ \\
\hline 2-Phenyl ethanol & $141 \pm 9.24$ & $203 \pm 18.38$ & $*$ \\
\hline Total of alcohols & $175 \pm 14.89$ & $267 \pm 26.92$ & $*$ \\
\hline \multicolumn{4}{|l|}{ C-6 compounds } \\
\hline 1-Hexanol & $35 \pm 7.07$ & $40 \pm 4.24$ & ns \\
\hline E-3-Hexen-1-ol & $9 \pm 1.41$ & $9 \pm 1.26$ & ns \\
\hline Total of C-6 compounds & $44 \pm 8.48$ & $49 \pm 4.24$ & ns \\
\hline \multicolumn{4}{|l|}{ Terpenes } \\
\hline Linalol & $7 \pm 0.8$ & $8 \pm 1.45$ & ns \\
\hline$\alpha$-Terpineol & $21 \pm 0.0$ & $27 \pm 1.41$ & $*$ \\
\hline Trans pyran linalol oxyde & $4 \pm 0.62$ & $7 \pm 0.85$ & $* * *$ \\
\hline Trans furan linalol oxyde & $43 \pm 4.24$ & $44 \pm 3.10$ & ns \\
\hline Citronellol & $7 \pm 0.60$ & $19 \pm 1.28$ & $* *$ \\
\hline Nerol & $140 \pm 10.14$ & $195 \pm 14.40$ & $*$ \\
\hline Geraniol & $194 \pm 9.79$ & $496 \pm 22.62$ & $* *$ \\
\hline 3,7-Dimethyl-1,5-octadiene-3,7-diol & $60 \pm 1.61$ & $102 \pm 9.62$ & $* *$ \\
\hline Linalol hydrate & $46 \pm 3.82$ & $150 \pm 22.60$ & $*$ \\
\hline 3,7-Dimethyl-1,7-octadiene-3,6-diol & $7 \pm 0.42$ & $19 \pm 1.96$ & $* *$ \\
\hline Total of terpenes & $529 \pm 48.98$ & $1067 \pm 79.27$ & $* *$ \\
\hline \multicolumn{4}{|l|}{ Fatty acids } \\
\hline Hexanoic acid & $58 \pm 4.25$ & $60 \pm 8.48$ & ns \\
\hline Nonanoic acid & $17 \pm 1.78$ & $17 \pm 2.36$ & ns \\
\hline Decanoic acid & $171 \pm 29.69$ & $178 \pm 24.04$ & ns \\
\hline Benzoic acid & $31 \pm 4.24$ & $79 \pm 11.31$ & $*$ \\
\hline Dodecanoic acid & $17 \pm 4.39$ & $30 \pm 5.65$ & ns \\
\hline Total of acids & $294 \pm 44.35$ & $364 \pm 51.84$ & ns \\
\hline \multicolumn{4}{|l|}{ Phenols } \\
\hline 4-Vinylguaiacol & $6 \pm 1.28$ & $16 \pm 2.82$ & $*$ \\
\hline 4-Vinylphenol & $6 \pm 1.41$ & $14 \pm 3.65$ & $*$ \\
\hline Vanilline & $7 \pm 1.78$ & $8 \pm 2.98$ & ns \\
\hline 2-(4-guaiacyl)-ethanol & $62 \pm 6.42$ & $49 \pm 5.65$ & ns \\
\hline $\begin{array}{l}\text { Syringaldehyde + 4-hydroxy } \\
\text { benzaldehyde }\end{array}$ & $143 \pm 19.79$ & $150 \pm 20.87$ & ns \\
\hline Tyrosol & $256 \pm 38.29$ & $280 \pm 53.84$ & ns \\
\hline Total of phenols & $480 \pm 68.98$ & $517 \pm 71.71$ & ns \\
\hline \multicolumn{4}{|l|}{ C-13 norisoprenoids } \\
\hline 3-Hydroxy- $\beta$-damascone & $31 \pm 0.98$ & $45 \pm 1.71$ & $* *$ \\
\hline $3-O x o-\alpha$-ionol & $30 \pm 2.69$ & $39 \pm 2.82$ & $*$ \\
\hline Total of C-13 norisoprenoids & $61 \pm 3.68$ & $84 \pm 4.54$ & $*$ \\
\hline Total of precursors & 1583 & 2348 & \\
\hline
\end{tabular}

${ }^{a}$ The results are given as mean of two replications (six injections on GC) with standard deviations

${ }^{b}$ Sig: Significance at which means differ as shown by analysis of variance; *, **, *** denote significances at $\mathrm{P}<0.05, \mathrm{P}<0.01$ and $\mathrm{P}<0.001$, respectively; ns: not significant 


\section{4. Sensory evaluation}

Sensory analysis of Muscat of Alexandria wines were carried out by 7 trained judges using triangle test. The significance was determined from detailed statistical tables (ROESSLER et al., 1978). Six out of 7 judges indicated that there was a significant difference between control and skin contact treated wines $(\mathrm{P}<0.01)$. Five judges from those 6 preferred skin contact wine. From aromatic point of view, skin contact treated wine bore more intense and more terpene-like character than control wine.

\section{Conclusions}

The skin contact treatment at $15^{\circ} \mathrm{C}$, for $7 \mathrm{~h}$ affected general and aromatic composition of Muscat of Alexandria wine. The total concentrations of free and bound aroma compounds of the wine increased considerably with the skin contact. The results of the gas chromatographic data and sensory evaluation showed that skin contact treatment under the condition of the investigation, improved the aroma intensity (particularly terpene-like character) and wine quality of Muscat of Alexandria wine. However, this study should be expanded to different skin contact times and temperatures at the same region for the production of high quality wines.

This work was financially supported by The Scientific and Technical Research Council of Turkey (TUBITAK-TOGTAG-1263). The authors would like to express their gratitude to Dr. Z. GUNATA and J.P. LEPOUTRE from INRA-IPV-Montpellier (France) for their help in GC-MS analysis.

\section{References}

ANON (1990a): Üzüm Çeşitleri Kataloğu. (Grape varieties catalogue.) Tarým ve Köyişleri Bakanliǧi, no:15, Ankara.

ANON (1990b): Recueil des methodes internationales d'analyse des vins et des moûts. Office International de la Vigne et du Vin, Paris.

ARNOLD, R.A. \& NOBLE, A.C. (1979): Effect of pomace contact on the flavor of Chardonnay wines. Am. J. Enol. Vitic., 30, 179-181.

Baumes, R.L., Bayonove, C, BArillere, J.M., Escudier, J.L. \& Cordonnier, R. (1989a): La macération pelliculaire dans la vinification en blanc. Incidence sur la composante volatile des moûts. Conn.Vigne Vin, 22, 209-223.

Baumes, R.L., Bayonove, C, Cordonnier, R.E., Torres, P. \& Seguin, A. (1989b): Incidence de la macération pelliculaire sur la composante aromatique des vins doux naturels de Muscat. Rev. Fr. Oenolog., 116, 6-11.

BAyonove, C. \& CoRdonnieR, R. (1971): Recherches sur l'arome du muscat. III. Etude de la fraction terpenique. Ann. Technol. Agric., 20, 347-355.

Cabaroglu, T., Canbas, A., Baumes, R., Bayonove, C., Lepoutre, J.P. \& Gunata, Z. (1997): Aroma composition of a white wine of Vitis vinifera L. cv. Emir as affected by skin contact. J. Fd Sci., 62, 680-683. 
Cheynier, V., Rigaud, J., Souquet, J.M., Barillere, J.M. \& Moutounet, M. (1989): Effect of pomace contact and hyperoxidation on the phenolic composition and quality of Grenache and Chardonnay wine. Am. J. Enol. Vitic., 40, 36-42.

Di Stefano, R. (1981): Composti terpenici del Moscato bianco del Piemonte. Vini Ital., 23, $29-43$.

Dubourdieu, D., Ollivier, C.H. \& Boidron, J.N. (1986): Incidence des opérations préfermetaires sur la composition chimique et les qualités organoleptiques des vins blanc secs. Conn. Vigne Vin, 20, 53-76.

Dugelay, I., GunAtA, Y.Z., SAPIS, S.C., BAumes, R. \& BAYONOVE, C. (1993): Role of cinnamoyl esterase activities from enzyme preparations on formation of volatile phenols during winemaking, J. agric. $F d$ Chem., 41, 2092-2096.

Etievant, P.X. (1991): Wine. -in: MAARSE, H. (Ed.) Food and beverages. Marcel Dekker. Inc., New York, pp. 483-546.

FALQUE, E. \& FERNANDEZ, E. (1996): Effect of different skin contact times on Treixadura wine composition. Am. J. Enol. Vitic., 47, 309-312.

Gomez, E., Martinez, A. \& LAENCINA, J. (1994): Localization of free and bound aromatic compounds among skin, juice and pulp fractions of some grape varieties. Vitis, 33, 1-4.

Gunata, Z., BAyonove, C.L., Baumes, R.L. \& CoRdonnier, R.E. (1985a): The aroma of grapes. I. Extraction and determination of free and glycosidically bound fraction of some grape aroma components. J. Chromat., 331, 83-90.

Gunata, Z., Bayonove, C.L., BAumes, R.L. \& CordonnieR, R.E. (1985b): The aroma of grapes. Localisation and evolution of free and bound fraction of some grape aroma components cv. muscat during first development and maturation. J. Sci. Fd Agric., 36, 857-862.

GunAtA, Y.Z., BAyonove, C.L, BAuMES, R.L. \& CoRdonnier, R.E. (1986): Stability of free and bound fractions of some aroma components of grapes cv. muscat during the wine processing: preliminary results. Am. J. Enol. Vitic., 37, 112-114.

HARDY, P.J. (1970): Changes in volatiles of muscat grapes during ripening. Phytochemistry, 9, 709-715.

MACHEIX, J.J., SAPIS, J.C. \& FlEURIET, A. (1991) Phenolic compounds and polyphenoloxidase in relation to browning in grapes and wines.Crit. Rev. Fd Sci. Nutr., 30, 441-486.

MARAIS, J. (1983): Terpenes in the aroma of grapes and wines. S. Afr. J. Enol. Vitic., 4, 49-58.

MARAIS, J. \& RAPP, A. (1988): Effect of skin-contact time and temperature on juice and wine composition and wine quality. S. Afr. J. Enol. Vitic., 9, 22-30.

Moyano, L., Moreno, J., Millan, C. \& Medina, M. (1994): Flavor in Pedro Ximenez grape musts subjected to maceration processes. Vitis, 33, 87-91.

Nykanen, L. \& SuOmalainen, A. (1989): Aroma of beer wine and distilled alcoholic beverages. D. Reider Publishing Company, London, pp. 272-280.

OugH, C.S., (1969): Substances extracted during skin contact with white musts. I. General wine composition and quality changes with contact time. Am. J. Enol. Vitic., 20, 93-100.

Ramey, D., Bertrand, A., Ough, C.S., Singleton, V.L. \& Sanders, E. (1986): Effect of skin contact temperature on Chardonnay must and wine composition. Am. J. Enol. Vitic., 37, 99-106.

Ribereau-Gayon, P., Boidron, J. N. \& Terrier, A. (1975): Aroma of muscat grape varieties. J. agric. Fd Chem., 23, 1042-1047.

Ribereau-Gayon, J., Peynaud, E., Sudraud, P. \& Ribereau-Gayon, P. (1976): Traite d'oenologie. Tome 1. Analyse et controle des vins. Dunod, Paris, pp. 471-513.

Roessler, E.B., Pangborn, R.M., Sidel, J.L. \& Stone, H. (1978): Expanded statistical tables for estimating significance in paired preference, paired-difference, duo-trio and triangle tests. J. Fd Sci., 43, 940-943.

Sefton, M.A., Francis, I.L. \& Williams, P.J. (1993): The volatile composition of Chardonnay juices: A study by flavor precursor analysis. Am. J. Enol. Vitic., 44, 359-370.

SINGLETON, V.L, (1974): Analytical fractionation of the phenolic substances of grapes and wines and some practical uses of such analyses. -in: WEBB, A.D. (Ed.), Chemistry of winemaking. American Chemical Society, Washington DC., pp. 184-211.

Singleton, V.L. \& Kramling, T.E. (1976): Browning of white wines and an accelerated test for browning capacity. Am. J. Enol. Vitic., 27, 157-160. 
Singleton, V.L., ZaYA, E. \& Trousdale, E. (1980): White wine quality and polyphenol composition as affected by must $\mathrm{SO}_{2}$ content and pomace contact time. Am. J. Enol. Vitic., 31, 14-20.

TeST, S.L., NoBlE, A.C. \& SCHMIDT, J.O. (1986): Effect of pomace contact on Chardonnay musts and wines. Am. J. Enol. Vitic., 37, 133-136.

Voirin, S.G., BAumeS, R.L., BitTeuR, S.M., GunATA, Y.Z. \& BAYONOVE, C.L. (1990): Novel monoterpene disaccharide glycosides of Vitis vinifera grapes. J. agric. Fd Chem., 38, 1373-1378.

Voirin, S.G., Baumes, R., Gunata, Z., BitTeur, S.M., Bayonove, C.L. \& TAPiero, C. (1992a) Analytical methods for monoterpene glycosides in grape and wine. I. XAD-2 extraction and GC-MS determination of synthetic glycosides. J. Chromat., 590, 313-328.

VoIRIN, S.G., BAUMES, R.L., SAPIS, J.C. \& BAYONOVE, C.L. (1992b): Analytical methods for monoterpene glycosides in grape and wine. II. Qualitative and quantitative determinations of monoterpene glycosides in grape. J. Chromat., 595, 269-281.

Williams, P.J., StRauss, C.R. \& WiLSON, B. (1980): Hydroxylated linalool derivatives as precursors of volatile monoterpenes of muscat grapes. J. agric. Fd. Chem., 28, 766-771.

Williams, P.J., SeFTON, M.A. \& Wilson, B. (1989): Nonvolatile conjugated of secondary metabolites as precursors of varietal grape flavor components. -in: TERANISHI, R., BUtTERY, R.G., SHAHIDI, F. (Eds.) Flavor chemistry trends and developments. American Chemical Society, Washington DC. USA, pp. $35-48$.

Wilson, B., Strauss, C.R. \& Williams, P.J. (1986): The distribution of free and glycosidically bound monoterpenes among skin, juice, and pulp fractions of some white grape varieties. Am. J. Enol. Vitic., 37, $107-111$ 